[Agr. Biol. Chem., Vol. 25, No. 4, p. 272 280, 1961]

\title{
Studies on the Pentose Isomerases of Lactic Acid Bacteria*
}

\author{
Part IV.* Effects and Requirement of Metal
}

\author{
By Kei Yamanaka \\ Laboratory of Microbiology, Faculty of Agriculture, Kagawa University, Kagawa
}

Received September 5, 1960

\begin{abstract}
D-Xylose isomerase requires manganese ions for its action, but $\mathrm{L}$-arabinose isomerase has a less specific on metal requirement. L-Arabinose isomerase is activated by addition of $\mathrm{Mn}^{++}$ or $\mathrm{Co}^{++}$, less effectively by addition of $\mathrm{Zn}^{++}, \mathrm{Ca}^{++}, \mathrm{Mg}^{++}, \mathrm{Sr}^{++}$or $\mathrm{Cd}^{++}$. Moreover, manganese and potassium ions for $\mathrm{D}$-xylose isomerase, and manganese and cobaltous ions for L-arabinose isomerase were also shown to have protective effect on respective enzymes against thermal inactivation.
\end{abstract}

\section{INTRODUCTION}

It has been well known that many enzymes require metallic ions for its action. In some of these enzymes metals are firmly bound with the enzyme proteins, but in others they are combined only loosely with the enzymes ${ }^{1)}$. Enzymes belonging to the first group do not lose metals during the course of purification, but may be inactivated by a forced removal of metals. In the second group of enzymes, the metals dissociate during the purification, and can be easily removed by dialysis. Many metals were reported to activate one or more enzymes, such as $\mathrm{Na}^{+}, \mathrm{K}^{+}, \mathrm{Mg}^{++}, \mathrm{Mn}^{++}, \mathrm{Ca}^{++}$, $\mathrm{Cu}^{++}, \mathrm{Co}^{++}, \mathrm{Fe}^{++}, \mathrm{Mo}^{++}, \mathrm{Zn}^{++}, \mathrm{Ni}^{++}$and so on. Concerning these important roles of metals on the activation of enzymes, many investigations were carried out ${ }^{1 \sim 5)}$.

In our previous papers on the pentose iso-

* The former serial title is corrected as above. So the reports under "Studies on the Pyruvate and Carbohydrate Metabolisms by Lactic Acid Bacteria" are corrected as follows: Parts $\left.\mathrm{IX}^{6}\right), \mathrm{X}^{7}$ ) and $\mathrm{XI}^{8}$ ) under former title are corrected to Parts I, II and III, respectively.

1) B.G. Malmström and A. Rosenberg, Adv. in Enzymol., 21, 131 (1959).

2) E. Bamann and H. Trapmann, ibid., 21, 169 (1959).

3) A.E. Martell and M.L. Calvin, "Chemistry of the Metal Chelating Compounds"', Prince-Hall, 1952, p. 401.

4) A.L. Lehninger, Physiol. Rev., 30, 393 (1950).

5) M. Dixon and E.C. Webb, "Enzymes", Longmans, Green \& Co., 1958, p 448 . merases $^{6 \sim 8)}$, magnesium chloride was used a priori as an activator in the isomerase reaction, but no attempt was made to clarify the role of metallic ions on the enzyme action. D-Xylose isomerases from Pseudomonas hydrophila $^{9}$ and from Pasteurella pestis ${ }^{10)}$ were reported to require manganese or magnesium ions for their activities. Magnesium ions were less effective for both cases.

Pentose isomerases of lactic acid bacteria were not inactivated by dialysis against water, but they were easily inactivated by treatment with EDTA** followed by dialysis against water. The addition of manganese ions restored the pentose isomerase activities of these inactivated enzyme preparations. Cobaltous ions were effective only for L-arabinose isomerase. Further evidences on the effects of metals and of inhibitors are presented in this paper.

\footnotetext{
6) K. Yamanaka, Bull. Agr. Chem. Soc. Japan, 22, 299 (1958).

7) K. Yamanaka, ibid., 24, 305 (1960).

8) K. Yamanaka, ibid., 24, 310 (1960).

9) R.M. Hochster and R.W. Watson, Arch. Biochem. Biophys., 48, 120 (1954).

10) M.W. Slein, J. Am. Chem. Soc., 77, 1663 (1955).

** The following abbreviations were used: Tris, Tris-(hydroxymethyl)-aminomethane; EDTA, disodium salt of ethylenediamine tetraacetate ; pCMB, sodium salt of $p$-chloromercuribenzoate and 2, 4-DNP, 2, 4-dinitrophenol.
} 


\section{METHODS}

\section{Preparations of Enzymes}

L-Arabinose isomerase was partially purified from extracts of L-arabinose-grown cells of Lactobacillus gayonii. This bacterium showed strong L-arabinose isomerase activity, while production of $\mathrm{D}$-xylose isomerase was still low in the $\mathbf{L}$-arabinose-medium ${ }^{8)}$. For the production of $\mathrm{D}$-xylose isomerase, Lactobacillus brevis was used. This bacterium produced a large amount of $\mathbf{D}$-xylose isomerase, but only a small amount of $\mathbf{L}$-arabinose isomerase in the $\mathbf{D}$-xylose-medium ${ }^{8}$. Stock cultures of these organisms were maintained in agar-stabs containing one per cent of $\mathrm{L}$-arabinose or $\mathrm{D}$-xylose, respectively, and stored at $6^{\circ} \mathrm{C}$.

The organisms were grown as described below. The medium was composed of 1 per cent peptone, 1 per cent yeast extract, 1 per cent sodium acetate, 0.02 per cent $\mathrm{MgSO}_{4} \cdot 7 \mathrm{H}_{2} \mathrm{O}, 0.001$ per cent $\mathrm{MnSO}_{4} \cdot 4 \mathrm{H}_{2} \mathrm{O}, 0.001$ per cent $\mathrm{FeSO}_{4} \cdot 7 \mathrm{H}_{2} \mathrm{O}, 0.001$ per cent $\mathrm{NaCl}$, and a sugar as carbon source. Microorganisms were incubated in test tubes with $8 \mathrm{ml}$ cach of a liquid-medium containing one per cent of pentose for 20 hours at $37^{\circ} \mathrm{C}$. The culture was then transferred to $200 \mathrm{ml}$ of the same pentose-medium and was grown for 20 hours, then it was transferred to 2.51 of the same medium containing one per cent $\mathrm{D}$-xylose and 0.1 per cent glucose for $\mathrm{D}$-xylose isomerase production, or 0.6 per cent L-arabinose and 0.5 per cent glucose for L-arabinose isomerase production. Pentoses were effective not only for the production of respective enzymes ${ }^{8)}$, but also for promoting better growth of these heterofermenters ${ }^{8,11,12)}$.

After 24 hours culture, cells were harvested by centrifugation and washed twice with cold $0.02 \mathrm{M}$ $\mathrm{NaHCO}_{3}$ solution. Freshly separated cell pastes were stored at $-10^{\circ} \mathrm{C}$ in frozen state, or were used immediately for preparation of cell-free extracts. About seven to eight grams of wet cells ground with $20 \mathrm{~g}$ of levigated alumina for five to eight minutes in the cold, extracted with ten times volume of chilled $0.05 \mathrm{M}$ $\mathrm{NaHCO}_{3}$, and centrifuged at $13,000 \times \mathrm{g}$ for thirty minutes. The precipitated cells were re-extracted once more with five times volume of $0.05 \mathrm{M} \mathrm{NaHCO}_{3}$. Yield of enzyme by second extraction was 10 to 15 per cent of the first extracts. First and second extracts were combined (Crude extracts), and all further procedures were carried out in the ice-cold. To the crude extracts containing about 3.0 to $5.0 \mathrm{mg}$ of protein per $\mathrm{ml}, 0.05$ volume of $\mathrm{M} \mathrm{MnCl}_{2}$ was added, and the resulted precipitate was removed by centrifugation (Mn-treated extracts). Solid ammonium sulfate was added to Mntreated extracts to 0.60 saturation, and the precipitate was discarded (Fraction A). Further addition of solid ammonium sulfate was made to 0.90 saturation. The precipitate was collected, dissolved in $0.1 \mathrm{~m}$ phosphate

Table I. Preparation of Pentose Isomerase

A. D-Xylose isomerase (L. brevis)

\begin{tabular}{|c|c|c|c|c|c|c|}
\hline \multirow[b]{2}{*}{ Fraction } & \multirow{2}{*}{$\begin{array}{l}\text { Volume } \\
\text { (ml) }\end{array}$} & \multirow{2}{*}{$\begin{array}{l}\text { Protein } \\
\text { (mg) }\end{array}$} & \multicolumn{2}{|c|}{ Xylose isomerase } & \multicolumn{2}{|c|}{ Arabinose isomerase } \\
\hline & & & $\begin{array}{l}\text { Specific } \\
\text { activity }\end{array}$ & $\begin{array}{l}\text { Total } \\
\text { unit }\end{array}$ & $\begin{array}{l}\text { Specific } \\
\text { activity }\end{array}$ & $\begin{array}{c}\text { Total } \\
\text { unit }\end{array}$ \\
\hline Crude extracts & 80 & 386 & 1.49 & 574 & 0.08 & 30.8 \\
\hline Mn-treated extracts & 80 & 142 & 5.62 & 800 & 0.34 & 48 \\
\hline Ammonium sulfate $(0 \sim 0.6$ sat. $)$ fraction & 13.4 & 40 & 0.35 & 13.7 & 0.03 & 1.1 \\
\hline Ammonium sulfate $(0.6 \sim 0.9$ sat. $)$ fraction & 13.2 & 29 & 12.9 & 378 & 0.58 & 16.9 \\
\hline \multicolumn{7}{|l|}{ B. L-Arabinose isomerase ( $L$. gayonii) } \\
\hline \multirow[b]{2}{*}{ Fraction } & \multirow{2}{*}{$\begin{array}{l}\text { Volume } \\
\text { (ml) }\end{array}$} & \multirow{2}{*}{$\begin{array}{l}\text { Protein } \\
\text { (mg) }\end{array}$} & \multicolumn{2}{|c|}{ Arabinose isomerase } & \multicolumn{2}{|c|}{$\mathrm{Xylose}$ isomerase } \\
\hline & & & $\begin{array}{l}\text { Specific } \\
\text { activity }\end{array}$ & $\begin{array}{l}\text { Total } \\
\text { unit }\end{array}$ & $\begin{array}{l}\text { Specific } \\
\text { activity }\end{array}$ & $\begin{array}{l}\text { Total } \\
\text { unit }\end{array}$ \\
\hline Crude extracts & 90 & 477 & 1.85 & 882 & - & - \\
\hline Mn-treated extracts & 90 & 205 & 4.87 & 999 & - & - \\
\hline Ammonium sulfate $(0 \sim 0.6$ sat. $)$ fraction & 16.5 & 77 & 0.32 & 24.7 & 0 & 0 \\
\hline Ammonium sulfate (0.6 0.9 sat.) fraction & 13.0 & 40 & 14.6 & 590 & 0.22 & 8.8 \\
\hline
\end{tabular}

11) M.N. Camien and M.S. Dunn, Proc. Soc. Exp. Biol. Med., 90, 183 (1955).

12) S.A. Koser and J.L. Thomas, ibid., 95, 89 (195i). 
buffer at $\mathrm{pH} 7.4$ and insoluble residues were removed. This solution was dialyzed against $0.02 \mathrm{M}$ phosphate buffer at $\mathrm{pH} 7.4$ and then against distilled water over 40 hours at $6 \pm 1{ }^{\circ} \mathrm{C}$ (Fraction B). This fraction was mainly used in this experiment. Further fractionation was carried out with acetone for L-arabinose isomerase, and the last acetone fraction (acetone $40 \sim 60$ per cent) contained 25 per cent of the original activity. This step accomplished 10 fold increase in specific activity. Typical data for preparations of enzymes are shown in Table I. Enzyme preparations were stored at $-10^{\circ} \mathrm{C}$ in frozen state without loss of activity over one month.

\section{Activity Measurement}

Enzyme was added to $0.5 \mathrm{ml}$ of tris buffer of $\mathrm{pH} 7.4$ and other ingredients, filled up to $2.8 \mathrm{ml}$ with distilled water, and preincubated at $30^{\circ} \mathrm{C}$ for ten (or five) minutes, then 20 micromoles of pentose ( $\mathrm{L}$-arabinose or D-xylose) were added, and reaction was proceeded at $37^{\circ} \mathrm{C}$ for ten minutes. Ketopentose was determined by cysteine-carbazole method $^{13)}$, and protein by Lowry's method ${ }^{14)}$.

A unit of enzyme was defined as the quantity which produces one micromole of ketopentose from aldopentose under those conditions, and specific activity was expressed as unit of enzyme per $\mathrm{mg}$ of protein.

\section{RESULTS}

\section{Effects of Inhibitors}

Both on D-xylose and I-arabinose isomerases from lactic acid bacteria, effects of several inhibitors including chelating agents and sulfhydryl or oxidizing reagents were examined. Experiments were performed repeatedly in duplicate or triplicate with enzyme preparations of different batches (25 to $130 \mu \mathrm{g}$ of protein used). These results were summarized in Table II. Data are shown as averaged value and relative activity is expressed as per cent. With ten minutes' incubation of enzyme with these inhibitors (final concentration at $\left.10^{-3} \mathrm{M}\right)$, no or little inhibitory effects were observed except EDTA. Chelating agents, such as $\alpha, \alpha^{\prime}$-dipyridyl, $o$-phenanthroline, and 8-hydroxyquinoline did not show any appreciable inhibitory effect. Moreover, other metal-

\footnotetext{
13) Z. Dische and E. Borenfreund, J. Biol. Chem., 192, 583 (1951).

14) O.H. Lowry, N.J. Rosenbrough, A.L. Forr and R.T. Randall.,
}

trapping materials such as pyrophosphate, organic acids, cyanide and azide did not inhibit enzyme activity. Only fluoride showed a little inhibitory effect (about ten per cent inhibition). EDTA showed strongly inhibi-

TABLE II. EFFECT OF INHIBITORS

\begin{tabular}{|c|c|c|c|}
\hline \multirow{2}{*}{\multicolumn{2}{|c|}{ Inhibitor (final, $10^{-3} \mathrm{M}$ ) }} & \multicolumn{2}{|c|}{ Relative activity $(\%)$} \\
\hline & & \multirow{2}{*}{$\begin{array}{l}\mathrm{D}-\mathrm{X} y \text { lose } \\
\text { isomerase }\end{array}$} & \multirow{2}{*}{$\begin{array}{l}\text { L-Arabinose } \\
\text { isomerase }\end{array}$} \\
\hline A. & Chelating agent & & \\
\hline & None & 100 & 100 \\
\hline & EDTA & 97.3 & 36.7 \\
\hline & $\alpha, \alpha^{\prime}-$ Dipyridyl & 100.8 & 108.4 \\
\hline & o-Phenanthroline & 95.7 & 109.2 \\
\hline & 8-Hydroxyquinoline & 91.0 & 111 \\
\hline & Na-Pyrophosphate & 100.0 & 96.4 \\
\hline & $\mathrm{K}_{2}$-Oxalate & 104.5 & 88.7 \\
\hline & $\mathrm{K}_{3}$-Citrate & 98.2 & 92.0 \\
\hline & $\mathrm{Na}_{2}$-Malonate & 104 & 96.2 \\
\hline & Chromotropic acid & 125.5 & 95.2 \\
\hline & $\mathrm{NaF}$ & 85.5 & 87.0 \\
\hline & $\mathrm{KGN}$ & 102.5 & 90.5 \\
\hline & $\mathrm{NaN}_{3}$ & 104 & 91.2 \\
\hline \multirow[t]{6}{*}{ B. } & Sulfhydryl reagent & & \\
\hline & None & 100 & 100 \\
\hline & Na-Monoiodoacetate & 107.8 & 87.5 \\
\hline & pCMB & 86.2 & 98.5 \\
\hline & Cysteine & 95.2 & 109 \\
\hline & Cystine & 103.5 & 105.5 \\
\hline \multirow[t]{4}{*}{ G. } & Oxidizing reagent & & \\
\hline & None & 100 & 100 \\
\hline & $o$-Iodosobenzoate & 99.0 & 92.0 \\
\hline & $\mathrm{K}_{3} \mathrm{Fe}(\mathrm{CN})_{6}$ & 103 & 101 \\
\hline \multirow[t]{13}{*}{ D. } & Others & & \\
\hline & None & 100 & 100 \\
\hline & 2,4-DNP & 107.5 & 93.0 \\
\hline & Hydoxylamine & 105 & 75.8 \\
\hline & Hydrazine & 105 & 71.5 \\
\hline & Semicarbazide & 104 & 76.5 \\
\hline & $m$-Phenylenediamine & 107 & 85.2 \\
\hline & Uracil & 93.2 & 76.8 \\
\hline & Urea & 97.4 & 86.7 \\
\hline & Urethane & 98.3 & 94.7 \\
\hline & Na-Arsenate & 91.4 & 102 \\
\hline & Na-Arsenite & 92.2 & 99.8 \\
\hline & Thiourea & 102 & 102.5 \\
\hline
\end{tabular}

After preincubation of enzyme with inhibitor at $30^{\circ} \mathrm{C}$ for $10 \mathrm{~min}$., reaction was proceeded with addition of pentose at $37^{\circ} \mathrm{C}$ for $10 \mathrm{~min}$. Addition of metal was omitted. 
tory effect on L-arabinose isomerase, and some results will be mentioned later. Sulfhydryl and oxidizing reagents, 2,4-DNP, urea and others were neither inhibitory nor stimulatory. Only slight inhibition was observed with addition of carbonyl reagents on L-arabinose isomerase. Furthermore, cysteine did not show stimulating effect on isomerase activity as shown in Table III.

TABLE III. EFFECT OF L-GYSTEINE ON L-ARABINOSE ISOMERASE ACTIVITY*

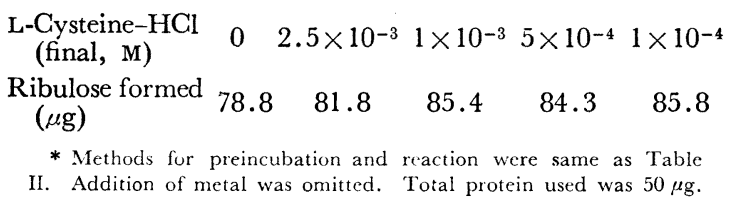

\section{Inhibition with EDTA and Reactivation by Metals}

L-Arabinose isomerase was strongly inhibited by EDTA at $10^{-4} \mathrm{M}$ in the final concentration (Table IV), while D-xylose isomerase was not inhibited at $10^{-3} \mathrm{M}$ of EDTA. However, addition of more concentrated solution of EDTA and prolonged treatment with EDTA caused considerable inhibition on D-xylose isomerase activity (Tables $\mathrm{V}$ and VI). So it may be concluded that pentose isomerases of lactic acid bacteria require metallic ions for their activities. Further studies on reactivation by metallic ions of EDTA-treated enzyme

TABLE IV. INHIBITION BY EDTA ON L-ARABINOSE ISOMERASE*

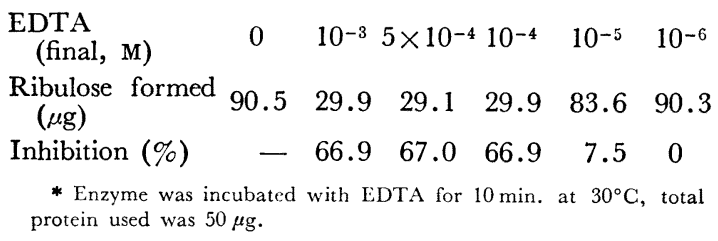

* Enzyme was incubated with EDTA for $10 \mathrm{~min}$. at $30^{\circ} \mathrm{C}$, total protein used was $50 \mu \mathrm{g}$.

TABLE V. INHIBITION BY EDTA ON D-XYLOSE ISOMERASE*

$\begin{array}{lrrrc}\text { EDTA (final, M) } & 0 & 10^{-2} & 5 \times 10^{-3} & 10^{-3} \\ \text { Xylulose formed }(\mu \mathrm{g}) & 105 & 66.6 & 96.0 & 104 \\ \text { Inhibition (\%) } & - & 36.5 & 8.6 & 0 \\ * \text { Enzyme was incubated with } & \text { EDTA for } & 10 \mathrm{~min} . \text { at } & 30^{\circ} \mathrm{C} \text {, total } \\ \text { protein used was } 110 \mu \mathrm{g} \text {. }\end{array}$

TABLE VI. INHIBITION BY EDTA ON D-XYLOSE ISOMERASE*

$$
\text { Xylulose formed }(\mu \mathrm{g})
$$

Time of Preincubation at $30^{\circ} \mathrm{C}(\mathrm{min})$ Without EDTA

$\begin{array}{cccc}15 & 30 & 60 & 90 \\ 131 & 136 & 148 & 115 \\ 102.3 & 66.5 & 46.0 & 35.8\end{array}$

$\left\{\begin{array}{l}\text { With EDTA } \\ \left.\quad \text { (final, } 10^{-2} \mathrm{M}\right)\end{array}\right.$

* Enzyme was incubated with and without EDTA at $30^{\circ} \mathrm{C}$ for a definite time noted in Table, and then D-xylose was added and reaction was proceeded at $37^{\circ} \mathrm{C}$ for $10 \mathrm{~min}$. Addition of metal was omitted. Protein, $110 \mu \mathrm{g}$.

were made on L-arabinose isomerase. In this experiment, EDTA was added to L-arabinose isomerase and the mixture was preincubated at $30^{\circ} \mathrm{C}$ for ten minutes, followed by the addition of metallic ions, incubation at $30^{\circ} \mathrm{C}$ for five minutes, and then the addition of 20 micromoles of L-arabinose and incubation at $37^{\circ} \mathrm{C}$ for ten minutes for the determination of enzyme activity. As seen in Table VII, among twelve cations, only manganese or

TABLE VII. REVERSAL ACTION BY METAL ON EDTA-INACTIVATED L-ARABINOSE ISOMERASE*

\begin{tabular}{|c|c|c|c|c|}
\hline \multirow[b]{2}{*}{ Metal } & \multicolumn{2}{|c|}{$I^{* *}$} & \multicolumn{2}{|c|}{$\mathrm{II} * * *$} \\
\hline & $\begin{array}{l}\text { Ribulose } \\
\text { formed } \\
(\mu \mathrm{g})\end{array}$ & $\begin{array}{l}\text { Relative } \\
\text { activity } \\
(\%)\end{array}$ & $\begin{array}{l}\text { Ribulose } \\
\text { formed } \\
(\mu \mathrm{g})\end{array}$ & $\begin{array}{l}\text { Relative } \\
\text { activity } \\
(\%)\end{array}$ \\
\hline $\begin{array}{l}\text { Without EDTA- } \\
\text { treatment**** }\end{array}$ & 73.5 & 100 & 58.1 & 100 \\
\hline$+\mathrm{MgSO}_{4}$ & 41.4 & 56.4 & 34.8 & 60.0 \\
\hline$+\mathrm{MnSO}_{4}$ & 86.3 & 117 & 82.7 & 145.2 \\
\hline$+\mathrm{CoCl}_{2}$ & 66.0 & 90 & 66.9 & 115 \\
\hline$+\mathrm{FeSO}_{4}$ & 46.7 & 63.5 & 34.3 & 59.2 \\
\hline$+\mathrm{Fe}_{2}\left(\mathrm{SO}_{4}\right)_{3}$ & 22.9 & 31.2 & 29.0 & 50.0 \\
\hline$+\mathrm{CuSO}_{4}$ & 21.1 & 28.8 & 27.3 & 47.1 \\
\hline$+\mathrm{ZnSO}_{4}$ & 43.2 & 58.8 & 45.4 & 78.2 \\
\hline$+\mathrm{NiSO}_{4}$ & 35.2 & 48.0 & 27.3 & 47.1 \\
\hline$+\mathrm{CdSO}_{4}$ & 34.3 & 46.0 & 37.0 & 63.8 \\
\hline$+\mathrm{CaCl}_{2}$ & 36.1 & 49.1 & 59.9 & 103 \\
\hline$+\mathrm{BaCl}_{2}$ & 28.3 & 38.5 & 27.3 & 47.1 \\
\hline$+\mathrm{SrCl}_{2}$ & - & - & 29.1 & 50.0 \\
\hline Without metal & 25.5 & 34.8 & 21.1 & 36.4 \\
\hline
\end{tabular}

* Protein used was $50 \mu \mathrm{g}$. Treated enzyme by EDTA for $10 \mathrm{~min}$. at $30^{\circ} \mathrm{C}$, then 20 micromoles of $\mathrm{L}$-arabinose added, and reaction was proceeded for $10 \mathrm{~min}$. at $37^{\circ} \mathrm{C}$.

** I. EDTA, $5 \times 10^{-4} \mathrm{M}$, metal, $10^{-8} \mathrm{M} ; * * *$ II. EDTA, $10^{-4} \mathrm{M}$, metal, $2 \times 10^{-1} \mathrm{M}$.

**** Enzyme was preincubted at $30^{\circ} \mathrm{C}$ for $15 \mathrm{~min}$, at $\mathrm{pH} 7.4$ without addition of EDTA. 
cobaltous ions had reactivating effects, and calcium ions were also effective in the case of inhibition by EDTA at $10^{-4} \mathrm{M}$. Addition of other divalent or trivalent cations had no effect.

\section{Effect of Metallic Ions}

An enzyme preparation was further dialyzed for 41 to 45 hours against distilled water at $2 \pm 1^{\circ} \mathrm{C}$, and the effect of added metallic ions on the enzymatic activity was determined. In this experiment, metallic ions were added to the dialyzed enzyme preparation, and the mixture was incubated at $30^{\circ} \mathrm{C}$ for five minutes at $\mathrm{pH}$ 7.4, before enzymatic reaction was initiated. As shown in Table VIII, the addition of manganese ions for D-xylose isomerase, and the addition of manganese, cobaltous and strontium ions for L-arabinose isomerase showed a stimulating effect on the enzyme activities. This effect by these metallic ions was observed at concentrations between $10^{-4}$ to $10^{-2} \mathrm{M}$ (Table IX). Magnesium, calcium, barium

TABle VIII. EFFEct of Metal

\begin{tabular}{|c|c|c|}
\hline \multirow[b]{2}{*}{$\begin{array}{c}\text { Metal } \\
\text { (final, } 10^{-3} \mathrm{M} \text { ) }\end{array}$} & \multicolumn{2}{|c|}{ Relative activity (\%) } \\
\hline & $\begin{array}{l}\text { L-Arabinose } \\
\text { isomerase* }\end{array}$ & $\begin{array}{c}\mathrm{D}-\mathrm{Xylose} \\
\text { isomerase** }\end{array}$ \\
\hline None & 100 & 100 \\
\hline$+\mathrm{MgSO}_{4}$ & 96.1 & 102.2 \\
\hline$+\mathrm{MnSO}_{4}$ & 130.5 & 183.5 \\
\hline$+\mathrm{CoGl}_{2}$ & 133 & 64.5 \\
\hline$+\mathrm{CuSO}_{4}$ & 6.4 & 39.3 \\
\hline$+\mathrm{ZnSO}_{4}$ & 51.2 & 37.3 \\
\hline$+\mathrm{FeSO}_{4}$ & 77 & 68.8 \\
\hline$+\mathrm{Fe}_{2}\left(\mathrm{SO}_{4}\right)_{3}$ & 14.7 & 76.7 \\
\hline$+\mathrm{BaCl}_{2}$ & 107.2 & 89.8 \\
\hline$+\mathrm{CaCl}_{2}$ & 112 & 61.1 \\
\hline$+\mathrm{NiSO}_{4}$ & 87.8 & 47.2 \\
\hline$+\mathrm{CdSO}_{4}$ & 79 & 69.0 \\
\hline$+\mathrm{SrCl}_{2}$ & 140 & 96.3 \\
\hline$+\mathrm{KGl}$ & 103 & - \\
\hline$+\mathrm{Li}_{2} \mathrm{SO}_{4}$ & 101 & - \\
\hline$+\mathrm{HgCl}_{2}$ & 0 & 35.6 \\
\hline
\end{tabular}

Table IX. Stimulatory Effect by Metal on PENTOSE ISOMERASES

\begin{tabular}{ccrrr}
\multicolumn{4}{c}{$\begin{array}{c}\text { Ribulose formed }(\mu \mathrm{g}) \\
\text { by arabinose } \\
\text { isomerase* }\end{array}$} & $\begin{array}{l}\text { Xylulose formed }(\mu \mathrm{g}) \\
\text { by xylose } \\
\text { isomerase** }\end{array}$ \\
Metal (final, M) & $\mathrm{MnSO}_{4}$ & $\mathrm{CoCl}_{2}$ & $\mathrm{SrCl}_{2}$ & $\mathrm{MnSO}_{4}$ \\
0 & 83.6 & 83.6 & 91.2 & 37.1 \\
$10^{-2}$ & 109 & 111.2 & 127.7 & 130.8 \\
$10^{-3}$ & 99.5 & 112.5 & 120.0 & 129.8 \\
$10^{-4}$ & 106.6 & 104.8 & 127.7 & 122.8 \\
$*$ Protein, $62.8 \mu \mathrm{g}:$ & $*$ & ** & Protein, $110 \mu \mathrm{g}$.
\end{tabular}

and mono-valent cations showed neither stimulatory nor inhibitory effect, but some di- and tri-valent cations, such as $\mathrm{Cu}^{++}, \mathrm{Zn}^{++}, \mathrm{Fe}^{+++}$, $\mathrm{Ni}^{++}, \mathrm{Cd}^{++}$and $\mathrm{Hg}^{++}$were inhibitory. Especially, $\mathrm{Cu}^{++}$and $\mathrm{Hg}^{++}$strongly inhibited the enzymatic activity even at lower concentrations $\left(10^{-4}\right.$ and $\left.10^{-5} \mathrm{M}\right)$.

\section{Cofactor Requirement}

As noted above, pentose isomerases from lactic acid bacteria were not inactivated by dialysis against water. It was found, however, that when EDTA was added to the enzyme before dialysis against water, isomerase was almost completely inactivated. From the results in Tables VII-IX, manganese or cobaltous ions seemed to be a cofactor for these enzymes. Other chelating agents, such as $\alpha, \alpha^{\prime}$-dipyridyl, $o$-phenanthroline and nitroso- $\mathrm{R}$ were less effective (Table $\mathrm{X}$ ) .

In order to demonstrate the metal requirement, the following technique was employed. To an enzyme preparation with suitable dilution, EDTA was added to $10^{-3} \mathrm{M}$ in final concentration, then this mixture was dialyzed against distilled water at $6^{\circ} \mathrm{C}$ for 42 hours or longer. After dialysis, the enzyme showed only slight activity ncver exceeding 10 per cent of the original activity. The activity was restored by the addition of manganese ions. With L-arabinose isomerase, the addition of manganese or cobaltous ions restored the isomerase activity, but zinc, cadmium, magnesium, calcium, or strontium was less effective. 
Table X. Treatment by Ghelating Agents on Dialysis

\begin{tabular}{|c|c|c|c|c|c|c|c|c|c|c|}
\hline \multirow{3}{*}{$\begin{array}{l}\text { Treated enzyme with* } \\
\text { Reaction with } 10^{-3} \mathrm{M} \mathrm{MnSO}_{4} \\
\text { Dialyzed for(hr.) }\end{array}$} & \multicolumn{8}{|c|}{ Xylulose formed ( $\mu \mathrm{g})$} & \multirow{2}{*}{\multicolumn{2}{|c|}{ Nitroso-R }} \\
\hline & \multicolumn{2}{|c|}{ Water } & \multicolumn{2}{|c|}{ EDTA } & \multicolumn{2}{|c|}{$\alpha, \alpha^{\prime}$-Dipyridyl } & \multicolumn{2}{|c|}{ o-Phenathroline } & & \\
\hline & - & + & - & + & - & + & - & + & - & + \\
\hline 0 & 94.7 & & & & & & & & & \\
\hline 17 & 55.0 & 73.2 & 14.1 & 96.7 & 80.7 & 74.8 & 38.4 & 70.4 & 55.8 & 81.2 \\
\hline 42 & 50.0 & 64.7 & 5.1 & 69.2 & 41.7 & 57.7 & 23.0 & 51.2 & 38.4 & 62.7 \\
\hline 65 & 41.7 & 55.0 & 6.4 & 82.6 & 29.4 & 64.0 & 35.2 & 97.3 & 33.2 & 71.0 \\
\hline 89 & 35.2 & - & 0 & 66.5 & 16.0 & 51.2 & 19.2 & - & 22.4 & $53.7^{\prime}$ \\
\hline
\end{tabular}

* $\mathrm{D}$-Xylose isomerase (protein, $1.94 \mathrm{mg} / \mathrm{ml} 2.0 \mathrm{ml}+$ water or chelating agent $\left(10^{-2} \mathrm{M}\right) 2.0 \mathrm{ml}$, mixture were dialyzed at $2 \pm 1^{\circ} \mathrm{C}$. One tenth $\mathrm{ml}$ of dialyzed enzyme solution were taken off at every interval for measurement of isomerase activity.

TABle XI. Metal ReQUiRement

\begin{tabular}{|c|c|c|c|}
\hline \multirow{2}{*}{ Metal added (final, M) } & \multicolumn{2}{|c|}{$\begin{array}{l}\text { D-Xylose isomerase* } \\
\text { Xylulose formed } \\
(\mu \mathrm{g})\end{array}$} & \multirow{2}{*}{$\begin{array}{l}\text { L-Arabinose } \\
\text { isomerase** } \\
\text { Ribulose formed } \\
(\mu \mathrm{g}) \\
10^{-3}\end{array}$} \\
\hline & $10^{-3}$ & $10^{-2}$ & \\
\hline None & 11.5 & 20.5 & 4.4 \\
\hline$+\mathrm{MgSO}_{4}$ & 18.5 & 26.2 & 14.5 \\
\hline$+\mathrm{MnSO}_{4}$ & 137.0 & 119 & 63.4 \\
\hline$+\mathrm{CoCl}_{2}$ & 32.0 & 33.3 & 52.4 \\
\hline$+\mathrm{FeSO}_{4}$ & 28.8 & - & 1.3 \\
\hline$+\mathrm{Fe}_{2}\left(\mathrm{SO}_{4}\right)_{3}$ & 30.7 & - & 4.8 \\
\hline$+\mathrm{ZnSO}_{4}$ & 19.2 & - & 22.4 \\
\hline$+\mathrm{BaCl}_{2}$ & 22.4 & - & 8.4 \\
\hline$+\mathrm{CaCl}_{2}$ & 25.6 & 33.3 & 15.4 \\
\hline$+\mathrm{NiCl}_{2}$ & 7.7 & - & 9.2 \\
\hline$+\mathrm{CdSO}_{4}$ & 18.5 & - & 10.1 \\
\hline$+\mathrm{SrCl}_{2}$ & 12.8 & 12.8 & 11.0 \\
\hline$+\mathrm{CuSO}_{4}$ & 11.5 & - & - \\
\hline$+\mathrm{KGl}$ & 17.3 & 33.3 & 5.7 \\
\hline$+\mathrm{NaCl}$ & 11.5 & 23.0 & - \\
\hline$+\mathrm{Li}_{2} \mathrm{SO}_{4}$ & 18.5 & 19.2 & 6.6 \\
\hline $\begin{array}{c}\text { Before dialysis } \\
\text { with } \mathrm{MnSO}_{4}\left(10^{-3} \mathrm{M}\right)\end{array}$ & 235.5 & 235.5 & 103.0 \\
\hline
\end{tabular}

Fig. 1 shows that full activity is attained with about $1 \times 10^{-4} \mathrm{M}$ of $\mathrm{Mn}^{++}$, or with $5 \times 10^{-4} \mathrm{M}$ of $\mathrm{Co}^{++}$. However, the degree of restoration of activity by addition of $\mathrm{Co}^{++}$ions is always lower than by $\mathrm{Mn}^{++}$. For $\mathrm{D}$-xylose isomerase, only manganese ions are able to restore the activity. Cobaltous, magnesium, iron (ferrous, ferric), calcium, barium, zinc, cadmium, or potassium ions show only little effect. Thus

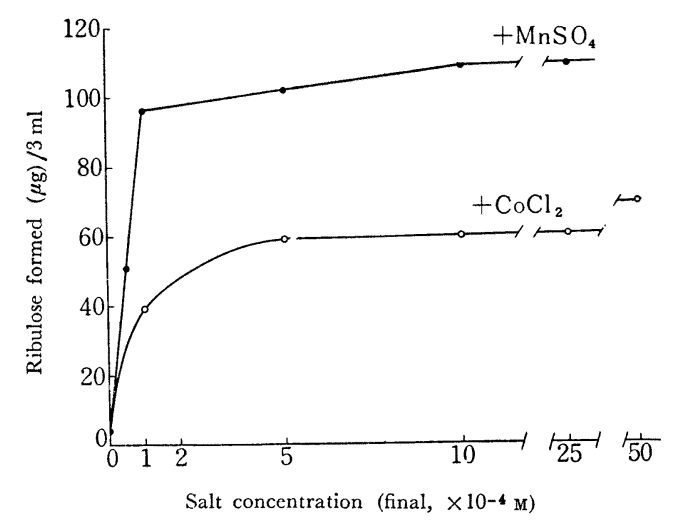

FIG. 1. Requirement of Metal on L-Arabinose Isomerase*

* EDTA-inactivated enzyme (EDTA, final $5 \times 10^{-4} \mathrm{M}$ ), proteir $64 \mu \mathrm{g} / 3 \mathrm{ml}$. Reaction condition was presented in the text.

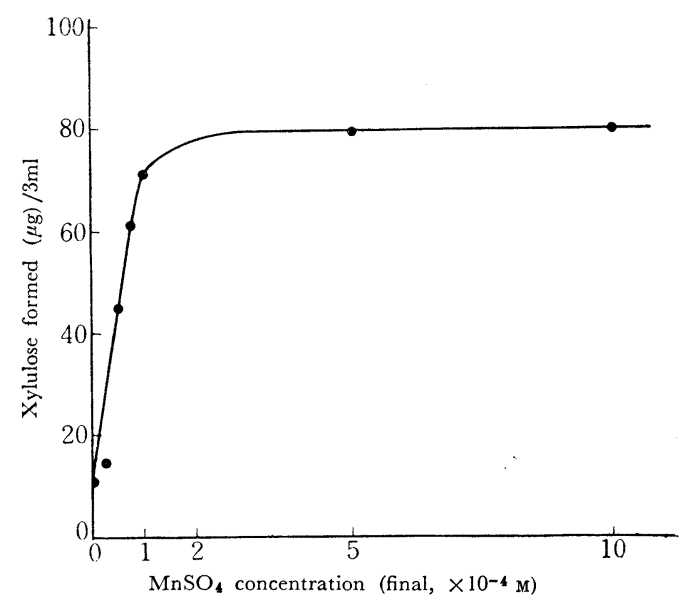

FIG. 2. Requirement of $\mathrm{Mn}$ ion on $\mathrm{D}-\mathrm{Xylose}$ Isomerase*

* EDTA-inactivated enzyme (EDTA, final $5 \times 10^{-3} \mathrm{M}$, dialyzed for $65 \mathrm{hrs}$.) protein $67.5 \mu \mathrm{g}$. 
it was concluded that D-xylose isomerase required manganese ions specifically, but Larabinose isomerase was less specific in the metal requirement.

\section{Effect of Metals on Thermal Inactivation}

Pentose isomerases were easily inactivated by heat treatment. As shown in Fig. 3, the incubation of the enzyme at $60^{\circ} \mathrm{C}$ over two minutes at $\mathrm{pH} 7.4$, destroyed the activity of D-xylose isomerase completely and that of L-arabinose isomerase to about 50 per cent. In this heat treatment of enzyme the addition of specific cofactors (metallic ions) protected the enzyme from thermal inactivation. Besides cofactors, in the case of D-xylose isomerase, potassium chloride, bromide or sulfate was effective in the protection, but potassium carbonate, tartarate or phosphate was completely inactive. Whereas the effect of potassium salts was observed only at very high concentrations, manganese was effective even at low concentrations as shown in Fig. 5. On the other hand, the effect of manganese or cobaltous ions for the protection of L-arabinose isomerase activity from thermal inactivation was observed at concentrations between 1

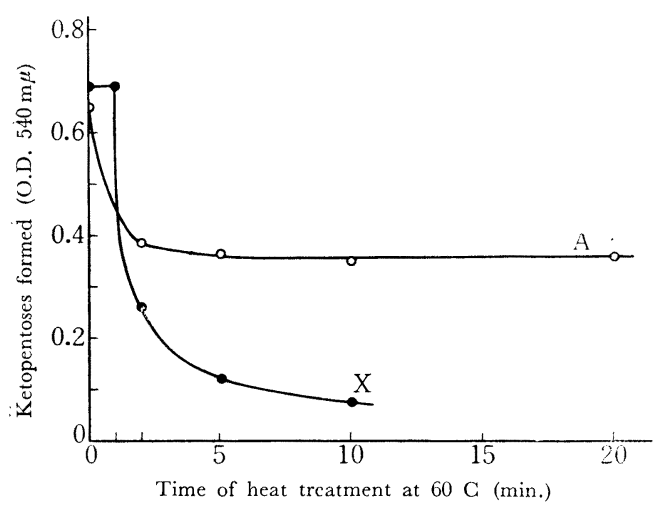

F1G. 3. Thermal Inactivation of Pentose Isomerase* Curve A. L-Arabinose isomerase (protein, $30.9 \mu \mathrm{g}$, specific activity 14.6)

Curve X. D-Xylose isomerase (protein, $95 \mu \mathrm{g}$, specific activity 23.4)

* Experimental conditions for the measurement of thermal inactivation see in Table XII.
Table XII. Effect of Metal on Thermal INACTIVATION

O.D. $540 \mathrm{~m} \mu$ by cysteine-carbazole

$\underset{\begin{array}{c}\text { Xylose } \\ \text { isomerase* }\end{array}}{\begin{array}{c}\text { Arabinose } \\ \text { isomerase** }\end{array}}$

Incubation time $\begin{array}{llllll}\text { at } 60^{\circ} \mathrm{C}(\mathrm{min} .) & 10 & 10 & 5 & 10 & 10\end{array}$

Salt (final, M) $2 \times 10^{-2} 10^{-3} \quad 2 \times 10^{-2} \quad 2 \times 10^{-2} \quad 10^{-3}$

$\begin{array}{llllll}\mathrm{KCl} & 0.428 & 0.034 & 0.630 & 0.327 & 0.402\end{array}$

$\begin{array}{lllllll}\mathrm{KBr} & 0.373 & - & - & 0.325 \quad-\end{array}$

$\mathrm{K}_{2} \mathrm{SO}_{4} \quad 0.387 \quad-\quad-\quad 0.288 \quad-$

$\mathrm{K}_{2} \mathrm{HPO}_{4} * * * * \quad 0.063 \quad-\quad 0.221 \quad-$

$\mathrm{K}_{2} \mathrm{CO}_{3} * * * \quad 0.067 \quad-\quad-0.238$ -

$\mathrm{K}_{2}$-Tartarate $0.128 \quad-\quad-\quad 0.330 \quad-$

$\begin{array}{llllll}\mathrm{NaCl} & 0.055 & 0.039 & 0.132 & 0.383 & 0.470\end{array}$

$\begin{array}{lllllll}\mathrm{Na}_{2} \mathrm{SO}_{4} & 0.018 \quad- & - & - & 0.347 & \text { - }\end{array}$

$\begin{array}{llllll}\mathrm{Li}_{2} \mathrm{SO}_{4} & 0.030 & 0.033 & 0.080 & 0.303 & 0.469\end{array}$

$\begin{array}{llllll}\mathrm{MgCl}_{2} & 0.004 & - & - & - & -\end{array}$

$\begin{array}{llllll}\mathrm{MgSO}_{4} & 0.007 & 0.070 & 0.012 & 0.353 & 0.372\end{array}$

$\begin{array}{lllllll}\mathrm{MnCl}_{2} & 0.023 \quad-\quad & - & 0.690 \quad-\end{array}$

$\begin{array}{llllll}\mathrm{MnSO}_{4} & 0.331 & 0.155 & 0.704 & 0.885 & 0.975\end{array}$

$\begin{array}{llllll}\mathrm{CoCl}_{2} & 0.038 & - & 0.048 & 0.534 & 0.580\end{array}$

$\begin{array}{llllll}\mathrm{BaCl}_{2} & 0.038 & - & 0.064 & - & 0.343\end{array}$

$\begin{array}{lllllll}\mathrm{CaCl}_{2} & 0.040 & - & - & - & 0.385 & 0.410\end{array}$

$\begin{array}{llllll}\mathrm{SrCl}_{2} & 0.042 & 0.024 & 0.068 & 0.407 & 0.440\end{array}$

$\begin{array}{lllllll}\text { None } & 0.028 & 0.005 & 0.071 & 0.286 & 0.348\end{array}$

$\begin{array}{cccccc}\begin{array}{c}\text { Without heat } \\ \text { treatment }\end{array} & 0.691 & 0.416 & 0.691 & 0.741 & 0.741\end{array}$

* Xylose isomerase (protein $95, \mu \mathrm{g}$, specific activity, 23.4).

** Arabinose isomerase (protein $30.9 \mu \mathrm{g}$, specific activity, 14.6).

*** $\mathrm{pH}$ was adjusted with $0.1 \mathrm{~N} \mathrm{HCl}$.

After treated enzyme at $60^{\circ} \mathrm{C}$ for definite tim and cooled in icebath, enzyme reaction was carried out with added $10^{-3} \mathrm{M}$ of $\mathrm{MnSO}$, and 20 micromoles of pentose at $37^{\circ} \mathrm{C}$ for $10 \mathrm{~min}$.

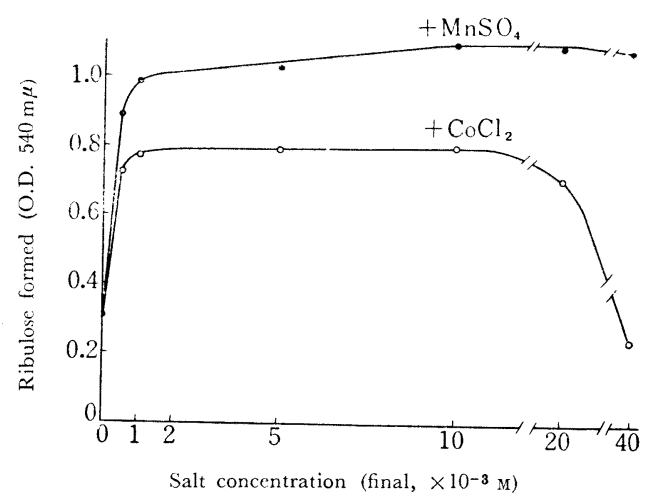

Fig. 4. Effect of $\mathrm{MnSO}_{4}$ and of $\mathrm{CoGl}_{2}$ on Thermal Inactivation of L-Arabinose Isomerase*

* Protein used, $30.9 \mu \mathrm{g}$, After heat-treatment, $10^{-3} \mathrm{M}$ of $\mathrm{MnSO}_{4}$ and $\mathrm{L}$-arabinose were added. 


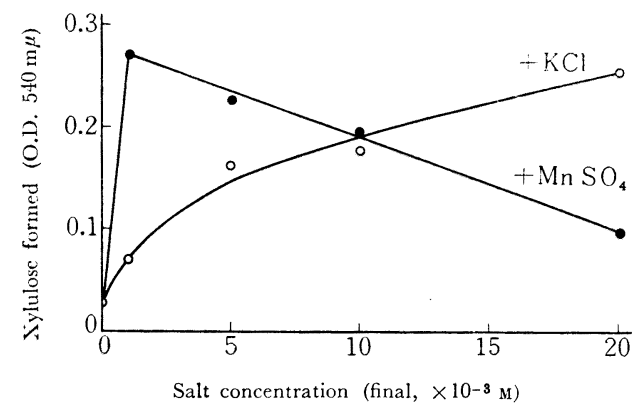

FIG. 5. Effect of $\mathrm{KGl}$ and of $\mathrm{MnSO}_{4}$ on Thermal Inactivation of D-Xylose Isomerase*

* Protein used, $110 \mu \mathrm{g}$. After heat-treatment, $10^{-3} \mathrm{M}$ of $\mathrm{MnSO}_{4}$ and $\mathbf{D}$-xylose were added.

$10 \times 10^{-3} \mathrm{M}$, and potassium salts were completely inactive.

\section{DISCUSSION}

A few reports are available on the inhibition study of pentose isomerase from bacteria. On D-xylose isomerase from Pasteurella pestis (Mn-treated, dialyzed preparation) ${ }^{10)}$, it has been reported that the enzyme was inhibited by $\mathrm{pCMB}\left(2.5 \times 10^{-3} \mathrm{M}\right)$ completely, and its activity was restored by addition of cysteine to 80 per cent of the original activity. The enzyme was stimulated by cysteine and, to a lesser extent, by glutathione in the absence of pCMB. Iodoacetate, iodoacetamide, N-ethylmaleimide and Tris inhibited the activity of this enzyme. With D-xylose isomerase from Pseudomonas hydrophila (sonic extracts, acetone powder) ${ }^{9)}$, activity was decreased to 20 to 30 per cents of the original activity by addition of 2,4-DNP, or 8-hydroxyquinoline at a final concentration of $10^{-2} \mathrm{M}$. But the addition of $\mathrm{pCMB}$, iodoacetate, adenine, adenosine, sulfanylamide, fluoroacetate, hydroxylamine, alloxan, citrate, urethane, fluoride and azide showed neither inhibition nor stimulation.

In this paper, D-xylose and L-arabinose isomerases from lactic acid bacteria were not inhibited by pCMB, iodoacetate, 2,4-DNP or 8-hydroxyquinoline at a final concentration of $10^{-3} \mathrm{M}$, in contrast to the $\mathrm{D}$-xylose isomerase described above. The activity of D-xylose isomerase from Pasteurella pestis was stimulated 2 to 3 fold by the presence of cysteine ${ }^{10}$, while the pentose isomerases from lactic acid bacteria were not stimulated by cysteine. So, it appears that pentose isomerases from lactic acid bacteria do not require sulfhydryl groups for their action.

Moreover, it has been found that L-arabinose isomerase from lactic acid bacteria is strongly inhibited by EDTA, and that the addition of $\mathrm{Mn}^{++}, \mathrm{Co}^{++}$or $\mathrm{Ca}^{++}$ions can restore the full activity of the EDTA-inactivated enzyme.

Further evidences have been presented here for the metal requirements of the enzymes. With dialyzed preparations, L-arabinose isomerase is stimulated by the presence of $\mathrm{Mn}^{++}$, and also by the presence of $\mathrm{Co}^{++}$or $\mathrm{Sr}^{++}$. Moreover, the enzyme was almost completely inactivated by treatment with EDTA followed by dialysis against water. The activity was restored by the addition of $\mathrm{Mn}^{++}$or $\mathrm{Co}^{++}$. Manganese and also magnesium ions were required also for $\mathrm{D}$-xylose isomerases from Pseud. hydrophila9) and from Pasteurella pestis $^{10)}$. D-Arabinose isomerase from $E$. coli $\mathbf{B}_{\mathrm{a} 15}$ was activated by the addition of manganese ions ${ }^{15}$.

\section{SUMMARY}

1. Pentose isomerases from lactic acid bacteria were not inhibited by $\alpha, \alpha^{\prime}$-dipyridyl, $o$ phenanthroline, 8-hydroxyquinoline, pyrophosphate, organic acids, cyanide, azide, monoiodoacetate, pCMB, cysteine, cystine, 2,4-DNP, urea, ferricyanide, o-iodosobenzoate, arsenate and arsenite.

2. L-Arabinose isomerase was strongly inhibited by EDTA, but D-xylose isomerase showed a considerable resistance against the EDTA-inhibition. With L-arabinose isomer-

15) D.M. Scott and S.S. Cohen, Biochem. J., 65, 686 (1957). 
ase, enzymatic activity was fully restored by addition of $\mathrm{Mn}^{++}, \mathrm{Co}^{++}$or $\mathrm{Ca}^{++}$ions after inactivation by EDTA.

3. $\mathrm{Mn}^{++}$for $\mathrm{D}$-xylose isomerase, and $\mathrm{Mn}^{++}$, $\mathrm{Co}^{++}$, or $\mathrm{Sr}^{++}$for L-arabinose isomerase showed stimulating effect, but $\mathrm{Cu}^{++}, \mathrm{Zn}^{++}$and $\mathrm{Hg}^{++}$ strongly inhibited both $\mathrm{D}$-xylose- and L-arabinose isomerase activities.

4. Pentose isomerases were inactivated by treatment with EDTA followed by dialysis against water. With addition of $\mathrm{Mn}^{++}$for D-xylose isomerase, and of $\mathrm{Mn}^{++}$or $\mathrm{Co}^{++}$for $\mathrm{L}$-arabinose isomerase, enzymatic activities were restored. Other cations were less effective. It seemed that $\mathrm{D}$-xylose isomerase required $\mathrm{Mn}^{++}$specifically and L-arabinose isomerase $\mathrm{Mn}^{++}$or $\mathrm{Co}^{++}$for their activities.

5. The cofactors were also effective for the protection of the enzymes from the thermal inactivation.

Addendum Dr. Lampen ${ }^{16)}$ presented in detail his data on the metal requirement of $\mathrm{D}$-xylose and $\mathrm{L}$-arabinose isomerases from $L$. pentosus. Both isomerases were inactivated by dialysis against $0.02 \mathrm{M}$ EDTA over-night. The metal requirement of $\mathrm{L}$-arabinose isomerase appeared to be considerably less specific than that of D-xylose isomerase. Addition of
$\mathrm{Mn}^{++}, \mathrm{Co}^{++}\left(10^{-4} \mathrm{M}\right)$ or $\mathrm{Ca}^{++}\left(10^{-3} \mathrm{M}\right)$ gave essentially the same maximal activity, and $\mathrm{Mg}^{++}, \mathrm{Ni}^{++}$, or $\mathrm{Zn}^{++}$were less effective on $\mathrm{L}$-arabinose isomerase. $\mathrm{D}$-Xylose isomerase was activated by $\mathrm{Mn}^{++}\left(10^{-4} \mathrm{M}\right)$, and slight activation was observed with $\mathrm{Ca}^{++}, \mathrm{Co}^{++}$, and $\mathrm{Mg}^{++}$ within about ten per cent of that obtained with $\mathrm{Mn}^{++}$.

We think that our results on metal requirement of pentose isomerases are essentially in agreement with those by Dr. Lampen.

The author is grateful to Dr. J. O. Lampen, Institute of Microbiology, Rutgers, the State University, New Jersey, U. S. A., for instructive informations of his unpublished data on this problem by $L$. pentosus.

Acknowledgments The author wishes to express his gratitude to Emeritus Prof. H. Katagiri, Kyôto University, for his constant interest and encouragement. $\mathrm{He}$ also wishes to acknowledge his indebtness to Prof. K. Kitahara, the Institute of Applied Microbiology, University of Tôkyo and to Prof. K. Katakura, Okayama University. He also would like to thank Prof. T. Hata, the Research Institute for Food Science, Kyôto University for helpful discussions on functions of sulfhydryl group and of metal on enzyme protein.

16) J.O. Lampen, Personal communication (September 15, 1960) . 